\title{
The Importance of Dream in Advertising: Luxury Versus Mass Market
}

\author{
Cesare Amatulli ${ }^{1}$, Matteo De Angelis ${ }^{2}$, Marco Pichierri $^{3} \&$ Gianluigi Guido ${ }^{4}$ \\ ${ }^{1}$ Ionian Department of Legal and Economic Mediterranean Systems: Society, Environment, Culture, University of \\ Bari, Taranto, Italy \\ ${ }^{2}$ Department of Business and Management, LUISS Guido Carli University, Rome, Italy \\ ${ }^{3}$ Department of Management, Alma Mater Studiorum University of Bologna, Bologna, Italy \\ ${ }^{4}$ Department of Economics Sciences, University of Salento, Lecce, Italy \\ Correspondence: Cesare Amatulli, Ionian Department of Legal and Economic Mediterranean Systems: Society, \\ Environment, Culture, University of Bari. Via Duomo, 259, 74123, Taranto, Italy.
}

\author{
Received: January 26, 2018 Accepted: February 18, 2018 Online Published: February 27, 2018 \\ doi:10.5539/ijms.v10n1p71 URL: https://doi.org/10.5539/ijms.v10n1p71
}

\begin{abstract}
Luxury companies typically follow managerial approaches that differ from those of mass market companies and, in particular, their marketing strategies are based on opposite tactics. For instance, luxury companies commonly use imagery rather than text in their print advertising as a way of allowing customers to assign their own personal meanings to the message, thus fulfilling their desire to dream. Indeed, in this current era of information proliferation, today's consumers are increasingly less willing to process advertising information they receive as text. In this study we explore luxury communication by analyzing some luxury brands' print advertisement and showing how luxury companies mainly communicate through images instead of text, thus creating appealing advertisements. On the basis of those results and some literature insights, we formulate some managerial propositions that mass market companies may use to start developing dream-evoking communication in order to appeal to modern consumers. In particular, we present mass market managers with suggestions about how to employ the luxury model to make their communications more aspirational than rational through imagery rather than text.
\end{abstract}

Keywords: luxury market, mass market, communication, print advertising, imagery, text

\section{Introduction}

With intense competition pervading today's business environment, differentiation is increasingly the key to success (Sharp \& Dawes, 2001). Product differentiation is still important, but nowadays the challenge in catching consumers' interest and involvement is "emotional differentiation" (Schmitt, 1999). Essential to the achievement of such a differentiation is companies' communication strategy and execution. However, developing an effective strategy in today's era is complicated by consumers' increasing "attention dilution": let's think about how often we leaf through print advertisements while simultaneously browsing the web or chatting on mobile devices.

The proliferation of information and media platforms has enormously increased content consumption and made consumers' attention more fragmented than in the past. One of the words that is currently used to describe this phenomenon is "snacking" (Carr, 2010), which captures the idea that today's multitasking individuals spend a lot of time shifting their attention across different media (e.g., mobile, the Internet, social networks), without dedicating significant attention to any single piece of information.

One salient effect of the digital and social revolution involves individuals' increased willingness to express their own identity compared to what happened some decades ago (Kotler, Kartajaya, \& Setiawan, 2010). As a result, companies are facing a growing pressure to rethink the ways in which they should deal with their current and potential customers, who now play a much more active role in their interaction with companies (Hanna, Rohm, \& Crittenden, 2011; The Boston Consulting Group, 2014). Such an active role is evident not only in the widespread use of social media platforms, through which consumers share ideas and feedback about companies, products and brands (Berger, 2009), but also in the way they react to commercial messages conveyed by companies. In simple terms, individuals are increasingly less interested in passively receiving companies' 
messages (Prahalad \& Ramaswamy, 2013) and prefer, by contrast, to freely assign their own meanings to those messages.

A relevant consequence of these developments is the dilution of consumers' "deep engagement" with companies' communication messages (Carr, 2010), which leads consumers to be particularly unreceptive to information delivered as text in advertisements. This happens for two main reasons. First, text requires a certain degree of cognitive processing and effort (Glenberg \& Robertson, 1999; MacInnis \& Jaworski, 1989). Second, when delivering information as text, companies uni-directionally assign a meaning to what they communicate, thus leaving little room for consumers' own personal interpretations. Moreover, luxury global brands often use English as lingua franca in order to deliver messages that can be interpreted in pretty much the same way globally (e.g., Crystal, 2003). Unfortunately, the consequence of this practice is the standardization of communication and the "homogenization" of consumers' interpretation, which also leads to the dilution of customer engagement. Therefore, in the modern era, a new communication approach is needed in order to revitalize consumer engagement practices.

Nowadays, many managers struggle to find an approach that best fulfills consumers' expectations. In response, we advocate a communication approach based on the strategic use of imagery in advertising, which allows customers to freely interpret advertising messages, thereby shaping their dreams. For guidelines, we turn to the business sector in which such an approach is not only well-established, but also occurs naturally: luxury. Our study begins with an analysis of the luxury sector, in which we explore the main values underlying the essence and purchase of luxury products. Then, we focus on one key element of the communication strategy typically used by luxury brands - namely the use of imagery rather than text in advertising as the best way to fulfill consumers' desire to dream - and document this practice through the qualitative research we conducted on luxury advertising. Next, we compare the luxury model with the mass market model, which has always been characterized by rational and informative advertising enacted with both text and images, rather than with images only. In light of consumers' increasing desire for personal interpretation of messages, we assert that mass market companies should adopt an approach similar to the one typical of the luxury companies. We conclude by summarizing our arguments and offering some clear prescriptions for mass market managers.

\section{Theoretical Background}

\subsection{The Luxury Model}

Luxury is a large and lucrative sector serving as one of the most relevant engines of growth in many countries (Bain \& Company, 2014). According to the research from The Boston Consulting Group-Fondazione Altagamma (2017), in 2016 the global luxury market was worth $€ 860$ billion. Interestingly, the average amount of annual sales for a Top 100 global luxury company recently reached US\$2.1 billion (Deloitte, 2017). Notwithstanding the wide-ranging effects of the 2008-2009 worldwide economic downturn (Spencer Stuart, 2009), the global luxury market has seen rapid growth over the past two decades (Fionda \& Moore, 2009; Kapferer, 2014; Truong, Simmons, McColl, \& Kitchen, 2008; Tynan, McKechnie, \& Chhuon, 2010), particularly in emerging countries where sudden economic growth has empowered middle-class consumers and allowed the luxury industry to thrive (Bain \& Company, 2017; The Boston Consulting Group, 2012).

Luxury goods are usually divided into four main categories: fashion goods, perfumes and cosmetics, wines and spirits, and watches and jewelry (Fionda \& Moore, 2009). Beyond this, there is no clear consensus on what really constitutes luxury and luxury brands (Eng \& Bogaert, 2010; Dubois \& Duquesne, 1993; Urkmez \& Wagner, 2015; Vickers \& Renand, 2003), mainly because the classification of products into luxury and non-luxury is highly dependent on the cultural context being analyzed (cf. Godey et al., 2013; Kemp, 1998; Veblen, 1899). However, scholars seem to agree that luxury brands are a complex combination of product quality, strong values, attention to details, and retail-control orientation (e.g., Amatulli \& Guido, 2011; Beverland, 2004). Case in point: names such as Louis Vuitton, Gucci or Cartier comprise what we traditionally define as luxury companies, and these brands are closely associated with words like style, design, creativity, craftsmanship, prestige, exclusivity, uniqueness, and quality. In other words, luxury goods are naturally associated with high design content and unique creativity. Their clear stylistic identity allows luxury products to reach an elite market.

One fundamental value of luxury goods is craftsmanship (cf. Kernstock, Brexendorf, \& Powell, 2017), which constitutes the basis for luxury brands' high quality standards and heritage aura. Craftsmanship in luxury is about hand-made products, rooted in the savoir fair of an artisan "elite" who have long been able to preserve a unique manufacturing tradition that allows luxury companies to constantly deliver excellence. However, delivering excellence takes time. Thus, the concept of time is an essential ingredient in creating value for luxury customers. As an example, manufacturing a Bottega Veneta leather bag requires many hours of highly specialized labor 
from dedicated and passionate artisans (Amatulli, De Angelis, Costabile, \& Guido, 2017). Time has an additional meaning in luxury: most prestigious luxury brands boast centuries of history. In other words, luxury brands have a heritage: just think about Louis Vuitton, which was founded in 1854, or Cartier, founded in 1847, or Chanel, founded in 1909. All these luxury brands hold a legendary history and a unique heritage, thus customers perceive them as authentic and prestigious. The implication of all this is that craftsmanship and time naturally limit production and legitimize high margins.

Of course, craftsmanship exists in varying degrees in other business contexts as well. Where luxury differs, however, is in its strong and natural association with aesthetics. Indeed, luxury artisans live by their ability to deliver unique products that combine top-quality manufacturing with high design content and strong aesthetical appeal. To accomplish this, artisans collaborate closely with the designer, a central figure in the luxury model whose stylistic identity is both shaped by and reflected in the artisan's products. In this way, artisans and designers develop, sustain and enhance the luxury brand DNA, thereby differentiating the brand in the market and solidifying its added value for customers.

In order to preserve the brand DNA without undermining long-term luxury brand profitability, it is essential to create and maintain a symbiosis between creativity and managerial skills. In simple terms, luxury companies should constantly pursue the right balance between the artistic (creative) soul and the rational (managerial) soul. Thus, the partnership model, whereby the designer and the manager share ideas and exert the same influence over the company's decision-making, is today considered the most successful approach. The success of Louis Vuitton in recent decades, for instance, depended crucially on the very close collaboration between designer Marc Jacobs and executive Yves Carcelle (cf. Amatulli, De Angelis, Costabile, \& Guido, 2017). When combined, these intrinsic elements of luxury suggest one guiding essence: namely, the creation and fulfillment of dreams.

\subsection{Communicating Dreams through Luxury}

The focus on fulfilling dreams carries with it an important implication: that luxury communication does not necessarily follow typical marketing mix rules (Kapferer \& Bastien, 2009, 2012; McCarthy, 1960), but priorities are brand image control and customer experience (Atwal \& Williams, 2009). Thus, luxury marketers need to think beyond traditional marketing schemes, seeing marketing as a process through which they can deliver products that allow luxury consumers to fulfill their aspirations and dreams (Dubois \& Paternault, 1995; Truong, McColl, \& Kitchen, 2010). As a consequence, the luxury model naturally leads to the so-called "anti-laws of marketing" (see Kapferer \& Bastien, 2009), such as:

- Selling to a niche market rather than to the mass market (indeed, luxury companies sometimes do not want to even sell to certain customers);

- A very low elasticity of demand to price (sometimes an increase in price may lead to more sales);

- A limited distribution (in contrast to non-luxury products, luxury goods need to be sold in a few, preferably company-owned, stores);

- Ever-increasing pricing (luxury brands usually strive to increase the price range of their products).

In our research on luxury brands, we found another key feature that defies traditional marketing: namely, the prevalence of imagery rather than text in the communication strategy.

\section{Method}

Twenty-six print advertisements from international luxury brands, published in fashion-specific magazines (e.g., Vogue), were selected by two researchers from a database provided by VisualBox s.r.l., an Italian market research company that specializes in the fashion industry. The database allows selecting all print advertisements related to certain brands, published in certain magazines, over a given period of time. The two researchers selected print advertisements of different page size (full-page or two-page) published in a same year (2011), ensuring that each advertisement was referred to one of the most valuable luxury brands (e.g., Louis Vuitton, Gucci, \& Hermès) defined according to a well-known international report (i.e., "The Interbrand Best Global Brands" ranking, http://www.bestglobalbrands.com/2014/ranking/). All the selected advertisements focused on high-end fashion products, i.e., clothing and accessories, as these categories represent the most traditional luxury consumables (Fionda \& Moore, 2009). The sample size was considered adequate for the purpose of the study, relying on previous works on semiotic analysis (Langrehr \& Caywood, 1995).

Two distinct researchers then analyzed the selected ads independently. Each of the two researchers received the ten advertisements one by one, in a randomized order, and they had thirty minutes to analyze each ad and to write down their findings. The two researchers filled in a detailed evaluation sheet for each print advertisement, 
in order to analyze all the graphic and semantic elements contained in each image. Specifically, graphical elements (i.e., colors, logotype presence, packshot), presence and composition of textual features (i.e., headline, bodycopy, claimed benefit, pay-off), presence of rhetorical tropes (e.g., metaphors), and conveyed meanings (i.e., surface meaning, cultural meaning, meaning at a figurative level) were examined and reported in the evaluation sheets. Additionally, the analysis of these elements was conducted considering the theoretical dichotomy between externalized $v s$. externalized luxury (Amatulli \& Guido, 2011), which describes the concept of luxury through a dichotomization between "externalized luxury" (i.e., considering luxury goods mainly as status symbols) and "internalized luxury" (i.e., perceiving luxury goods mainly as means to express an individual style). Therefore, each single aspect in the analysis was referred to one of these two opposite approaches. A complete example of the evaluation sheet used for the analysis is reported in Appendix A.

Most of the analyzed ads were about Italian and French brands, which have, since the fifties, enjoyed a global presence and an excellent reputation worldwide as superb creators of fashion products (White, 2000). In particular, with a sales volume of almost 50 billion euro in 2010, Italy alone represents $25 \%$ of the total turnover of the European fashion system and ranks third in the world for clothing export (SMI-ATI, 2010).

\section{Results}

Our analysis shows that fashion luxury companies typically develop advertising campaigns that mainly communicate through signs and images rather than text (e.g., words and numbers) in order to render their messages more interesting and involving for customers. As a consequence, luxury communication naturally relies on semiotics, which is the science of dealing with the meaning of signs (Mick, 1986). Theoretically, a sign is composed of three components: a sign, an object, and an interpretation (Goudge, 1969). When we translate this understanding to the commercial landscape, we find that "the consumer world is a web of meanings among consumers and marketers woven from signs and symbols" (Mick, 1986, p. 196). The field of semiotics suggests that companies should accommodate individual customers' interpretations in their advertising messages. While the advertiser typically arranges signs and symbols with some intent, it must be conceded that interpretation, which is the essence of semiotics (e.g., Bertrand, 1988), ultimately lies with the audience (Langrehr \& Caywood, 1995). Indeed, visual communication does not use language codes, but leaves the visual message and the viewer alone. In other words, it is the viewer that links together visual images, thus producing his/her own meaning (Bulut \& Yurdaisik, 2005).

Our research additionally found that in the few cases in which text is used, English is the dominant language. While there are practical reasons for this choice (e.g., disseminating factual information more efficiently to global audiences), the sole use of English might also lead to a standardized interpretation of the message, which may not effectively stoke the desire for dreaming. For more details about our research, please see Appendix A where we illustrate the framework by applying our analysis to one advertisement drawn from our sample. Additionally, Figure 1 (A-B) shows two examples of fashion luxury brand advertisements that use only imagery with no text. Specifically, Figure 1A features a Spring/Summer 2005 Louis Vuitton advertising campaign with Uma Thurman, while Figure 1B features a Spring/Summer 2015 Chanel campaign with Gisele Bundchen campaign. In both cases, no text is shown beyond the brand name.

A

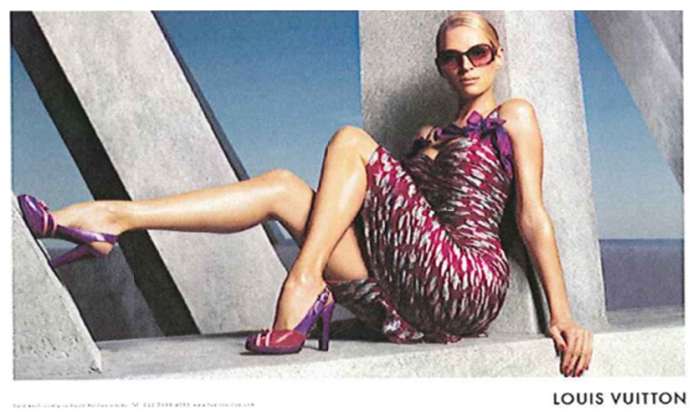

B

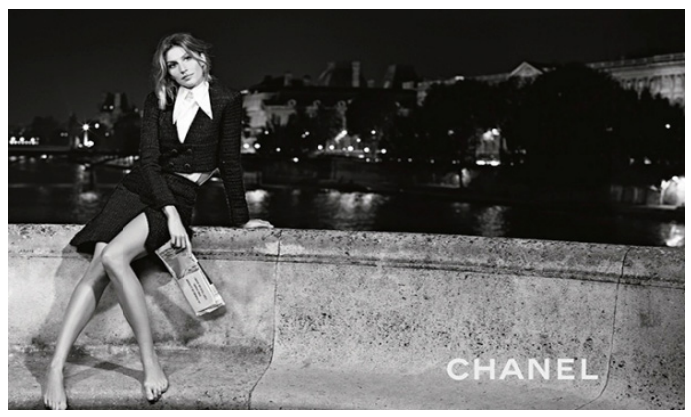

Figure 1. Examples of fashion luxury brand advertisements that use only imagery with no text 
Such a practice seems to be particularly consistent with the idea of highlighting the emotional and experiential aspects of luxury communication and consumption. In simple terms, the objective of generating memorable experiences and fostering consumers' aspirational desires (aspects that are a typical characteristic of luxury goods) can be better pursued through the use of imagery, because imagery leaves more room, when compared to plain text, for consumers to interpret the message conveyed, thus making them more likely to travel with their imagination - to dream.

Furthermore, with regard to the luxury dichotomy (externalized $v s$. internalized luxury), results revealed that most of the semiotic elements in the advertisements refer to internalized luxury positioning. This result could depend on the fact that selected advertisements were targeted to Western audiences, where the approach to luxury consumption is mainly linked to individual style than to status symbols, while the contrary happens in emerging countries (Wong \& Ahuvia, 1998).

\section{Discussion}

\subsection{Luxury Versus Mass Market}

While inspiring dreams is a natural practice for luxury companies, it is not so much for mass-market companies. However, in light of consumers' growing desire for advertising that can be personally interpreted, we claim that mass market brands should consider the luxury model and embrace a similar communication approach aimed at creating dreams.

The key difference in the communication strategies adopted by luxury versus mass market companies lies in the fact that the former mainly focus on creating dreams via strong aspirational messages, while the latter mainly focus on delivering product benefits and reasons to buy via strong rational messages. Such different objectives entail different communication tactics: while most luxury companies use no text at all in their advertisements, most mass market companies often use a lot of text. More specifically, most mass market companies use specific techniques aimed at convincing customers about the functional benefits of their products. For instance, many brands use numbers and percentages to describe the characteristics and benefits of their products. Moreover, they often focus their messages and visuals around a "before/after" situation. Both these techniques seek to strengthen the credibility of the message by pointing to the practical benefits of buying said products. Figures 2 provide two examples of such techniques, enacted by two widely known brands (L'Orèal's Revitalift cream-Fig. 2A and P\&G's Ariel laundry detergent Fig. 2B).

A

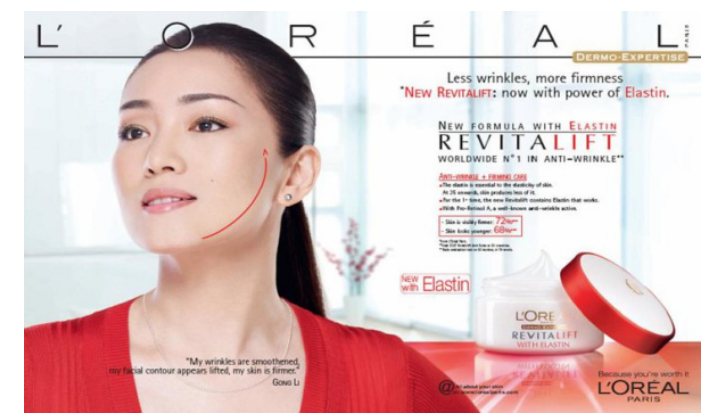

B

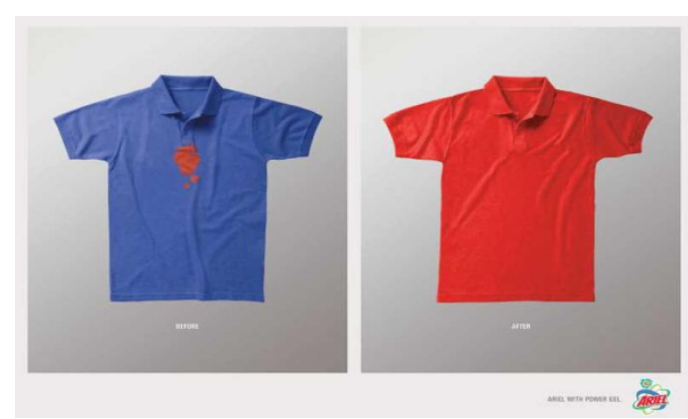

Figure 2. Examples of brand advertisements aimed at convincing customers about the functional benefits of their products

The use of such polarized communication approaches is rooted in the fact that consumers in mass market versus luxury contexts typically want to be targeted in opposite ways. Mass market consumers have traditionally been highly receptive toward rational, informative and standardized communication, while luxury consumers have always been targeted through aspirational, emotional and exclusive communication that makes them feel involved in a dream (Dubois \& Paternault, 1995). Table 1 provides a summary of the main differences between luxury and mass market. 
Table 1 . Key differences between luxury and mass markets

\begin{tabular}{lll}
\hline & Luxury & Mass market \\
\hline Target group expectation & Uniqueness and exclusivity & Convenience and functionality \\
Communication message strategy & Aspirational massages aimed at creating & $\begin{array}{l}\text { Rational messages based on product } \\
\text { dreams }\end{array}$ \\
Communication message execution & Imagery & Text, numbers and percentages \\
\hline
\end{tabular}

From our perspective, such a sharp split in communication strategies is no longer consistent with the evolution of modern consumers. Indeed, as we outlined in the introduction, today's consumers are deeply changing. With the emergence of multiple online platforms that allow individuals to widely access information as well as share and create content of any sort, today's customers are increasingly eager to play a central role in assigning their own meaning to the advertising they are exposed to. The consequence of such an evolution is quite disruptive, as the emerging desire to freely interpret communication content involves both luxury and mass market customers. In light of such a widespread change, even mass market companies may need to embrace communication strategies and tactics that have typically been the domain of the luxury model (i.e., communication messages aimed at creating dreams). In simple terms, our idea is that mass market companies should understand and employ to a greater extent the luxury communication approach of instilling dreams through the use of emotional and image-based communication.

\subsection{Prescriptions for Mass Market Managers}

The Given the explosion of information sources, today's consumers can access most information openly and freely, but at the same time, they have limited cognitive resources to process everything they get exposed to (e.g., Carr, 2010). Because it is practically impossible for consumers to accurately process such a vast amount of information, it is no longer feasible or desirable for them to act as passive recipients of companies' messages (Prahalad \& Ramaswamy, 2013). Consequently, they want to play a more active role by shaping company-created content via personal interpretation.

- Prescription 1: never forget that today's customers live in the era of "fragmented attention," which makes them less available to pay attention to conventional advertising in which message meanings are assigned by the company. Customers are eager to craft their own advertising meaning. Engage your customers more by allowing them to more freely interpret your messages.

Because the luxury model already appeals to customers' desire for free interpretation, it is a useful blueprint for inspiring customers to dream. For example, Louis Vuitton's "L'invitation au Voyage" campaign features a young woman starting her journey on an air balloon and enjoying a nice view of the city of Venice, being captured in a dream (see Figure 3A).

There is no text, only an image that leaves customers free to interpret and dream. Mass market brands have not traditionally adopted such an approach, for the obvious reason that their customers have typically focused on products' tangible benefits rather than dreaming. However, given the changing consumer landscape, mass market brands may benefit from adopting the luxury model as a new paradigm.

- Prescription 2: mass market managers should understand the luxury model in order to transfer its essential elements into their mass market model. They should adapt the luxury companies' model without merely imitating it. They should strive to inspire customers to dream about the product(s) they sell.

There are a few examples of mass market companies that have started applying a dream-evoking advertising approach. To illustrate, Zara, a fast fashion brand, uses imagery in its print advertisements with no text (see Figure 3B) in order to inspire its customers to dream, even though the brand is not a luxury one. In fact, Zara sells fairly basic and inexpensive fashion products, but its customers do not generally make their purchase decisions based only on rational assessment of costs and benefits, as they are moved by their desire to experience positive emotions.

Similarly, Intel, a non-luxury brand, designed the "New Era in Computing" campaign featuring a colored bird flying out of a laptop screen (see Figure 3C). Again, there was no text and no rational focus on the product (the focus was instead placed on the bird), only on imagination and dream. 
A
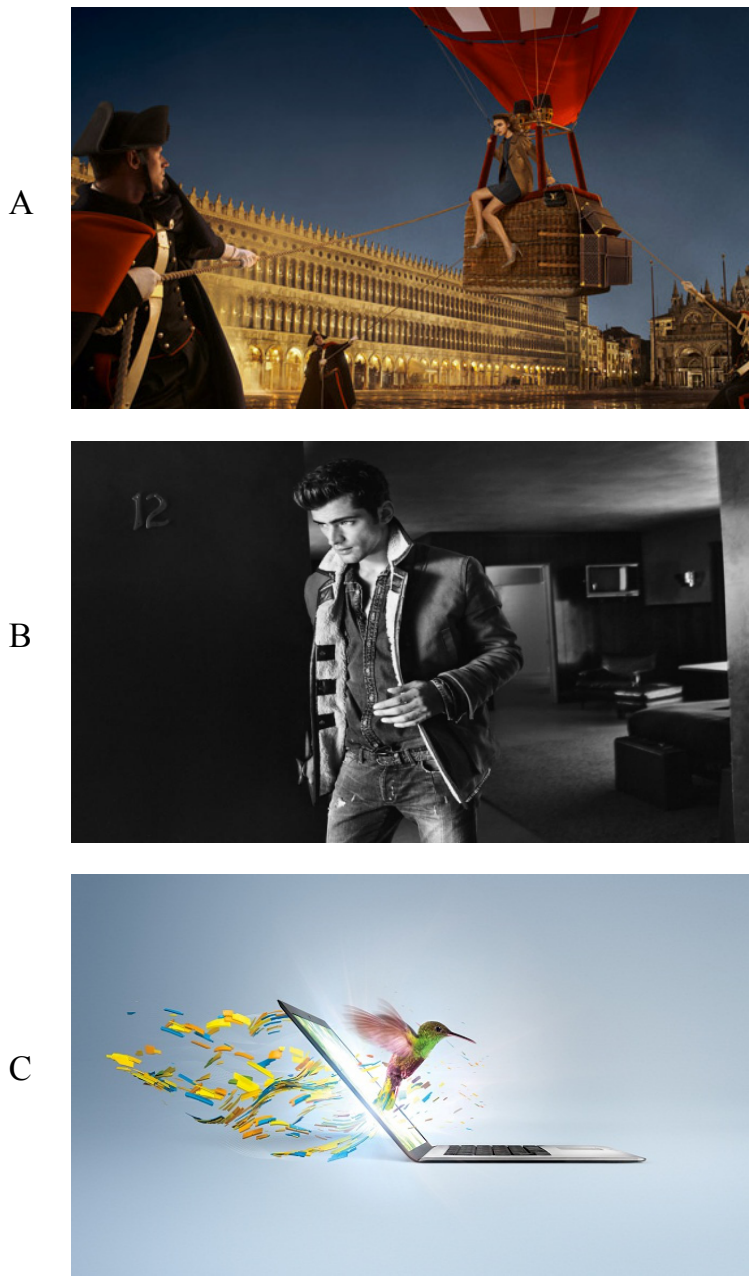

Figure 3. Examples of dream-evoking advertising approach (A. Louis Vuitton's "L'invitation au Voyage" campaign; B. Zara Fall/Winter 2012 campaign; C. Intel's New Era in Computing campaign)

These cases demonstrate that silent advertising is particularly important for triggering customers' interpretation and ability to dream. However, they also suggest that such a strategy needs to follow a semiotic logic, providing customers with an imagery architecture that allows them to "travel with their imagination." How should non-luxury companies execute their advertising strategy? What kind of tactics should they use when designing advertisements?

- Prescription 3: mass market managers should develop fewer rational and informative advertisements and learn from luxury companies about how to effectively use more dream-evoking advertising based on images rather than text. This is the best tactic for encouraging mass market customers to dream.

\section{Conclusions}

Competition today is very intense and differentiation has become increasingly crucial to garnering consumers' preferences. Wide access to information has made consumers not only well informed, but also eager to affirm their individuality when connecting with companies. This tendency is manifested in consumers' desire to assign their own meanings to advertising messages as a way to feel invested in the whole communication process.

We note that, while we advocate a convergence of the communication strategy adopted by mass market companies toward the communication strategy adopted by luxury companies, we do not believe that all mass market companies are the same. Indeed, the mass market category, which typically includes a much bigger number of industries than luxury, is composed of companies selling very many and different products. Relevant to our prescriptions, the different products included in the mass market category may have different potential to elicit aspiration and dream. For instance, one might think that categories such as regular personal care, consumer electronics and food products are more suitable for dream than categories such as batteries, laundry detergents 
and napkins. Despite these differences, however, we believe that advertising can help foster dreams and aspirations even for product categories that are less suited for adopting the luxury communication model. Finally, it is worth noticing that we do not claim that dream-evoking advertising can make mass market products be perceived as status symbols like luxury goods; rather, we claim that this type of advertising may create dreams and aspirations around mass market products as well.

To conclude, this paper offers three key messages to managers. First: consumers' habits across all industries have changed so dramatically that they now want a highly active role in their relationship with companies, which entails giving them the opportunity to form their own interpretations and, ultimately, to dream. Second: in order to fulfill consumers' desires, mass market companies need to understand the mechanism through which the luxury communication model is able to deeply engage customers and facilitate dreams. Third: mass market brands should embrace the practice of using less text in their advertising and more images in order to be less informative and more aspirational.

\section{References}

Amatulli, C., De Angelis, M., Costabile, M., \& Guido, G. (2017). Sustainable luxury brands: Evidence from research and implications for managers. London: Palgrave Macmillan. https://doi.org/10.1057/978-1-137-60159-9

Amatulli, C., \& Guido, G. (2011). Determinants of purchasing intentions of fashion luxury goods in the Italian market: A laddering approach. Journal of Fashion Marketing and Management, 15(1), 123-136. https://doi.org/10.1108/13612021111112386

Atwal, G., \& Williams, A. (2009). Luxury brand marketing-The experience is everything! Journal of Brand Management, 16(5-6), 338-346. https://doi.org/10.1057/bm.2008.48

Bain \& Company. (2014). Luxury goods worldwide market study, Fall-Winter 2014: The rise of the borderless consumer.

Retrieved from http://www.bain.com/publications/articles/luxury-goods-worldwide-market-study-december-2014.aspx

Bain \& Company. (2017). Luxury goods worldwide market study, Fall-Winter 2017. Retrieved from $\mathrm{http}$ //www.bain.com/publications/articles/luxury-goods-worldwide-market-study-fall-winter-2017.aspx

Berger, J. (2009). Contagious. Why things catch on. New York, NY: Simon \& Schuster.

Bertrand, D. (1988). The creation of complicity: A semiotic analysis of an advertising campaign for Black \& White whisky. International Journal of Research in Marketing, 4(4), 273-289. https://doi.org/10.1016/0167-8116(88)90030-4

Beverland, M. (2004). Uncovering "theories-in-use": Building luxury wine brands. European Journal of Marketing, 38(3/4), 446-466. https://doi.org/10.1108/03090560410518648

Bulut, T., \& Yurdaisik, A. (2005). Visual Semiotics and Interpretation in the Television Commercial. Applied Semiotics: A Learned Journal of Literary Research on the World Wide Web, 6(16), 46-53.

Carr, N. (2010). The shallows: What the Internet is doing to our brains. New York: WW Norton \& Company.

Crystal, D. (2003). English as a global language. Cambridge: Cambridge University Press. https://doi.org/10.1017/CBO9780511486999

Deloitte. (2017). Global powers of luxury goods 2017: The new luxury consumer. Retrieved from https://www2.deloitte.com/content/dam/Deloitte/global/Documents/consumer-industrial-products/gx-cip-gl obal-powers-luxury-2017.pdf

Dubois, B., \& Duquesne, P. (1993). The market for luxury goods: Income versus culture. European Journal of Marketing, 27(1), 35-44. https://doi.org/10.1108/03090569310024530

Dubois, B., \& Paternault, C. (1995). Understanding the world of international luxury brands: The "dream formula". Journal of Advertising Research, 35(4), 69-77.

Eng, T. Y., \& Bogaert, J. (2010). Psychological and cultural insights into consumption of luxury western brands in India. Journal of Customer Behaviour, 9(1), 55-75. https://doi.org/10.1362/147539210X497620

Fionda, A. M., \& Moore, C. M. (2009). The anatomy of the luxury fashion brand. Journal of Brand Management, 16(5-6), 347-363. https://doi.org/10.1057/bm.2008.45

Glenberg, A. M., \& Robertson, D. A. (1999). Indexical understanding of instructions. Discourse Processes, 28(1), 1-26. https://doi.org/10.1080/01638539909545067 
Godey, B., Pederzoli, D., Aiello, G., Donvito, R., Wiedmann, K. P., \& Hennigs, N. (2013). A cross-cultural exploratory content analysis of the perception of luxury from six countries. Journal of Product \& Brand Management, 22(3), 229-237. https://doi.org/10.1108/JPBM-02-2013-0254

Goudge, T. A. (1969). The thought of C.S. Peirce. New York: Dover Publications.

Hanna, R., Rohm, A., \& Crittenden, V. L. (2011). We're all connected: The power of social media ecosystem. Business Horizon, 54(3), 265-273. https://doi.org/10.1016/j.bushor.2011.01.007

Kapferer, J. N. (2014). The artification of luxury: From artisans to artists. Business Horizons, 57(3), 371-380. https://doi.org/10.1016/j.bushor.2013.12.007

Kapferer, J. N., \& Bastien, V. (2009). The specificity of luxury management: Turning marketing upside down. Journal of Brand Management, 16(5/6), 311-322. https://doi.org/10.1057/bm.2008.51

Kapferer, J. N., \& Bastien, V. (2012). The luxury strategy: Break the rules of marketing to build luxury brands (2nd ed.). London: Kogan Page Publishers.

Kemp, S. (1998). Perceiving luxury and necessity. Journal of Economic Psychology, 19(5), 591-606. https://doi.org/10.1016/S0167-4870(98)00026-9

Kernstock, J., Brexendorf, T. O., \& Powell, S. M. (2017). Introduction: Luxury Brand Management Insights and Opportunities. In J. N. Kapferer, J. Kernstock, T. O. Brexendorf, \& S. M. Powell (Eds.), Advances in Luxury Brand Management (pp. 1-24). Cham: Palgrave Macmillan. https://doi.org/10.1007/978-3-319-51127-6_1

Kotler, P., Kartajaya, H., \& Setiawan, I. (2010). Marketing 3.0: From products to customers to the human spirit. Hoboken, NJ: John Wiley \& Sons. https://doi.org/10.1002/9781118257883

Langrehr, F. W., \& Caywood, C. L. (1995). A semiotic approach to determining the sins and virtues portrayed in advertising. Journal of Current Issues and Research in Advertising, 17(1), 33-47. https://doi.org/10.1080/10641734.1995.10505024

MacInnis, D. J., \& Jaworski, B. J. (1989). Information processing from advertisements: Toward an integrative framework. Journal of Marketing, 53(4), 1-23. https://doi.org/10.2307/1251376

McCarthy, E. J. (1960). Basic marketing: A managerial approach. Homewood: Irwin.

Mick, D. G. (1986). Consumer research and semiotics: Exploring the morphology of signs, symbols and significance. Journal of Consumer Research, 13(2), 196-213. https://doi.org/10.1086/209060

SMI-ATI. (2010). L'industria tessile moda in Italia: Report 2010-11. SMI-ATI Federazione Imprese Tessili e Moda Italiane, Milan.

Prahalad, C. K., \& Ramaswamy, V. (2013). The future of competition: Co-creating unique value with customers. Harvard Business Press.

Schmitt, B. (1999). Experiential marketing. Journal of Marketing Management, 15(1-3), 53-67. https://doi.org/10.1362/026725799784870496

Sharp, B., \& Dawes, J. (2001). What is differentiation and how does it work? Journal of Marketing Management, 17(7-8), 739-759. https://doi.org/10.1362/026725701323366809

Spencer Stuart. (2009). Leadership in the luxury industry: Are the rules changing? Retrieved from http://content.spencerstuart.com/sswebsite/pdf/lib/luxleaders_rgb.pdf

The Boston Consulting Group. (2012). Luxe redux. Raising the bar for selling of luxuries. Retrieved from http://www.bcg.com/expertise_impact/publications/PublicationDetails.aspx?id=tcm:12-107254

The Boston Consulting Group. (2014). Evolution and revolution: How Insurers Stay Relevant in a Digital Future. Retrieved from http://www.bcg.com/expertise_impact/capabilities/technology/publicationdetails.aspx?id=tcm:12-170363\& $\mathrm{mid}=\mathrm{tcm}: 12-170362$

The Boston Consulting Group-Fondazione Altagamma. (2017). The true-luxury global consumer insight (4th ed.). $\quad$ Retrieved from https://altagamma.it/media/source/BCG\%20Altagamma\%20True-Luxury\%20Global\%20Cons\%20Insight\% 202017\%20-\%20presentata.pdf

Truong, Y., McColl, R., \& Kitchen, P. J. (2010). Uncovering the relationships between aspirations and luxury 
brand preference. Journal of Product \& Brand Management, 19(5), $346-355$. https://doi.org/10.1108/10610421011068586

Truong, Y., Simmons, G., McColl, R., \& Kitchen, P. J. (2008). Status and conspicuousness: Are they related? Strategic marketing implications for luxury brands. Journal of Strategic Marketing, 16(3), 189-203. https://doi.org/10.1080/09652540802117124

Tynan, C., McKechnie, S., \& Chhuon, C. (2010). Co-creating value for luxury brands. Journal of Business Research, 63(11), 1156-1263. https://doi.org/10.1016/j.jbusres.2009.10.012

Urkmez, T., \& Wagner, R. (2015). Is your perception of "luxury" similar to mine? A concept made of absolute and relative features. Journal of Euromarketing, 24(1), 20-40.

Veblen, T. (1899). The theory of the leisure Class. New York: Macmillan.

Vickers, J. S., \& Renand, F. (2003). The marketing of luxury goods: An exploratory study - Three conceptual dimensions. The Marketing Review, 3(4), 459-478. https://doi.org/10.1362/146934703771910071

White, N. (2000). Reconstructing Italian fashion: America and the development of the Italian fashion industry. New York: Berg Publishers.

Wong, N. Y., \& Ahuvia, A. C. (1998). Personal taste and family face: Luxury consumption in confucian and $\begin{array}{lllll}\text { western } \quad \text { societies. } & \text { Psychology } & \text { Marketing, } & \text { 15(5), } & 423-441 .\end{array}$ https://doi.org/10.1002/(SICI)1520-6793(199808)15:5<423::AID-MAR2>3.0.CO;2-9

\section{Appendix A}

\section{Example of Analysis Sheet}

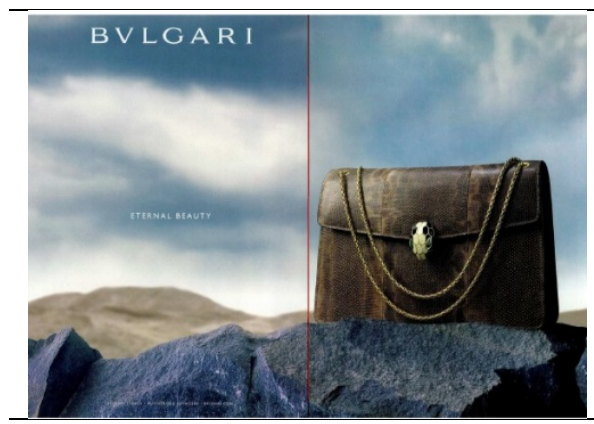

Brand Name/Country/Publisher

Bulgari/USA/Vogue USA

Page Size/Position/Page Space

Standard (about 8 by 10 inches)/ Second half of the issue/ Two-page spread

Surface Meanings

1) Bulgari is an accessory brand; 2) The brand is a leading company in precious leather goods; 3) The main values of the brand are beauty and durability

1) The advertiser wants to emphasize that buying a Bulgari's product means not only purchasing a nice item, but also making an investment (a good deal); 2) The durability of the

Advertiser's Intended Meanings products is the main value of the brand, which helps to justify the high price of a crocodile or python bag.

Nowadays, especially as a consequence of the global economic crisis, consumers (even the most affluent ones) pay more and more attention to the quality of products; they look for fair

Cultural/Ideological Meanings value items and are willing to pay a premium price only for purchases that can last for years (both in terms of duration and stylistic identity). Beauty alone is no longer acceptable

Headline (Int./Ext. Luxury Meanings) ETERNAL BEAUTY (The headline underlines the quality of the product and its aesthetical content, I)

Number of words (English words) $2(2)$

Bodycopy (Int./Ext. Luxury Meanings) None

Number of words (English words)

Pay-off (Int./Ext. Luxury Meanings) None

Number of words (English words)

Number of individuals (Main objects) $\quad 0(1)$

Logotype presence (Int./Ext. Luxury Meanings) Yes (The typical signature of the brand is on the top central part of the first page, I)

Packshot (Int./Ext. Luxury Meanings)

The bag is the main object of the ad; it is a precious bag and a bit in contrast with the context (desert, stones) (I) 
Benefit/Reason why/Tone of voice (Int./Ext. Luxury Meanings)

Figurative level

Plastic level

Rhetorical tropes
Durability (I)/ Durability and beauty (I)/ Secure (I)

The brand signature is the same color of clouds, therefore it doesn't really stand out.

Lines and shapes do not play a central role in the ad, except for the pointed and cutting lines of the rocks that stand in contrast with the more soft and smooth leather of the bag, which emphasizes those characteristics of the product's materials. At least 6 combined colors.

Metaphor $\mathrm{x} 1$ (The rocks represent energy and durability, their presence outlines the quality of the bag. The sky is also a symbol of nature, of something eternal and pleasant. A strong relationship between the product and natural elements is metaphorically implied. The contrast between the common soft touch of leather goods and the rough touch of the rocks represented in the ad reinforces the idea that the products of this brand are as durable and strong as thousand-year-old stones.)

\section{Copyrights}

Copyright for this article is retained by the author, with first publication rights granted to the journal.

This is an open-access article distributed under the terms and conditions of the Creative Commons Attribution license (http://creativecommons.org/licenses/by/4.0/). 